\title{
Relationship between serum iron and insulin-like growth factor-I concentrations in 10-day-old calves
}

\author{
Radiša Prodanović ${ }^{1}$, Danijela Kirovski², Ivan Vujanac ${ }^{1}$, Petar Dodovski \\ Ljubomir Jovanovićn ${ }^{2}$ Horea Šmanc ${ }^{1}$ \\ ${ }^{1}$ University of Belgrade, Faculty of Veterinary Medicine, Department of Farm Animal Diseases, \\ ${ }^{2}$ Department of Physiology and Biochemistry, Belgrade, Serbia \\ ${ }^{3}$ University St Kliment Ohridski-Bitola, Faculty of Veterinary Medicine, Department of Physiology, \\ Bitola, Former Yugoslav Republic of Macedonia
}

Received July 1, 2013

Accepted January 23, 2014

\begin{abstract}
Newborn calves are often deficient in iron and progressive reduction in blood iron concentration occurs over the first weeks of life. Some reports indicate the importance of interactions among iron and components of the insulin-like growth factor system. The aim of the study was to determine if there is a relationship between serum iron and insulin-like growth factor-I concentrations in neonatal calves. Blood samples were collected from 16 female Holstein-Friesian calves on day 10 of age. Erythrogram determination and measurements of serum iron, total protein, albumin, total iron binding capacity and serum insulin-like growth factor-I concentrations were performed. Haematological values were measured using an automatic analyzer, biochemical properties were determined spectrophotometrically, insulin-like growth factor-I concentration was measured by radioimmunoassay. Calves were divided into 2 groups according to iron concentrations; the first group of iron-deficient calves $(\mathrm{n}=8, \mathrm{Fe}<10 \mu \mathrm{mol} / \mathrm{l})$ and the second group of calves with optimal iron concentration $(\mathrm{n}=8, \mathrm{Fe}>18 \mu \mathrm{mol} / \mathrm{l})$. Blood indicators in all calves from the first group followed a pattern typically observed in anaemic calves. Insulin-like growth factor-I concentrations were significantly $(P<0.01)$ lower in the first group compared to the second group. However, insulin-like growth factor-I very strongly correlated with iron in calves from the second group compared to iron-deficient calves $(\mathrm{r}=0.624 ; P<0.01$ and $\mathrm{r}=0.478 ; P>0.05$, respectively). Based on our results, iron seems to have an important relationship to secretion of insulin-like growth factor-I in 10-day-old calves. This is the first report about such relationship in this age group of animals.
\end{abstract}

\section{Calf, haematology, IGF-I, iron deficiency}

Iron is an important trace mineral in young animals. Its normal metabolism is necessary to support growth, development, health and good functioning of the organism (Harvey 2008). According to Mohri et al. (2010), the amount of iron uptake by calves is not sufficient for normal erythropoiesis during at least the first month of life. It has been outlined that calves showing an iron value lower than $18 \mu \mathrm{mol} / \mathrm{l}$ at, or shortly after birth would be considered to be iron-deficient (Bostedt et al. 1990). The most severe consequence of this disorder is iron deficiency anaemia, which is considered to be common in the veal industry but not in calves fed roughage with concentrates and mineral/vitamin supplements (Lindt and Blum 1994). However, a significant incidence of anaemia in neonatal calves has been reported by Bostedt et al. (1990) and by Moosavian et al. (2010).

Insulin-like growth factor-I (IGF-I) is regulated at different levels; however, IGF-I in circulation is mainly produced in the liver (Cordano et al. 2000). It is mediated through provision of energy, nutrients, minerals and vitamins but likely also through the effects of non-nutritive factors (Guilloteau et al. 2002; Kirovski et al. 2008). Studies conducted on rodents and humans have revealed an important relationship between iron and the IGF system (specifically IGF-I) (Choi and Kim 2004; Tran

Phone: + 381628268092

Fax: + 381112685936

E-mail: dani@vet.bg.ac.rs

http://actavet.vfu.cz/ 
et al. 2012). Furthermore, among endocrine changes present in veal calves, some evidence links iron deficiency to decreased plasma IGF-I concentrations (Ceppi and Blum 1994; Blum and Hammon 1999). Interactions between iron and IGF-I may be also of relevance for the neonatal calf, since calves are usually exposed to subnormal iron concentration during the first month of life. To date, few reports have examined the activity of the GH-IGFs system in iron-deficient veal calves (Ceppi and Blum 1994; Blum and Hammon 1999).

The aim of the study was to determine whether IGF-I circulating in the blood of 10-dayold calves is influenced by altered iron status.

\section{Materials and Methods}

The study was performed at a commercial dairy farm where all calves are blood sampled every 10 days as a routine practice. According to serum iron concentration on day 10 of life, 16 female Holstein-Friesian calves were chosen for the study. The calves were single born after normal lenght of pregnancy and normal parturition. They were kept in a loose housing system on concrete floors bedded with straw. All calves were fed the pooled colostrums: $1.5 \mathrm{~kg}$ during the first hours of life then twice daily for the next $48 \mathrm{~h}(2 \mathrm{~kg} / \mathrm{calf})$. Thereafter, the calves were bottle-fed with $2.5 \mathrm{~kg}$ of herd milk at 08:00 and 16:00 $\mathrm{h}$. To ensure that all calves received an equal amount of milk, calves with a reduced appetite $(n=2)$ were, in addition, tube-fed the planned amounts.

Blood samples taken from each calf on day 10 were used for establishing selected haematological and biochemical indicators. Blood was collected by venipuncture $(10 \mathrm{ml})$, allowed to clot, centrifuged at $1800 \times g$ for $10 \mathrm{~min}$, aliquoted into $2-\mathrm{ml}$ microfuge tubes, and frozen at $-20^{\circ} \mathrm{C}$; another $2 \mathrm{ml}$ were collected in EDTA. Whole blood samples were analyzed for numbers of red blood cell (RBC), haemoglobin (Hb), haematocrit (HCT), mean corpuscular volume (MCV), mean corpuscular haemoglobin $(\mathrm{MCH})$ and mean corpuscular haemoglobin concentration $(\mathrm{MCHC})$ by an automatic veterinary haematology cell counter (Abacus Junior, France). The concentrations of serum iron (Fe), total protein and albumin and total iron binding capacity (TIBC) were measured spectrophotometrically by commercial kits (Human, Germany) using an autoanalyser (Vet Evolution, Italy). Insulin like growth factor-I (IGF-I) concentration was measured with radioimmunoassay (RIA; INEP, Serbia). The concentration of globulin was calculated as the difference between total serum protein and albumin concentrations.

The calves were divided into two equal groups $(n=8)$ based on the concentration of serum iron on day 10 of life. The calves of the first group (iron-deficient) had $\mathrm{Fe}<10 \mu \mathrm{mol} / 1$, and the calves of the second group (optimal iron concentration) had Fe $>18 \mu \mathrm{mol} / \mathrm{l}$. The two groups of calves were homogenous for parity of dams and birth weight. Average birth weights of calves were $36.34 \pm 2.61 \mathrm{~kg}$ (first group) and $36.81 \pm$ $3.57 \mathrm{~kg}$ (second group).

Data analyses were performed using STATISTICA version 6. software package (StatSoft, Inc., Tulsa, Ok, USA). Student's $t$-test was used to evaluate the differences of means between the two groups. Correlation coefficients were computed by Pearson's method. Kolmogorov-Smirnov test for normality and Levene's test for homogeneity of variances were used. The differences were considered significant at $P<0.05$.

\section{Results}

The results of selected haematological and serum biochemical indicators in relation to Fe concentrations are summarized in Tables 1 and 2. With the exception of $\mathrm{MCH}$, the differences of individual indicators between groups were significant. The $\mathrm{RBC}, \mathrm{Hb}$, HCT, and MCHC were lower $(P<0.001)$, whereas MCV and TIBC were higher $(P<$ $0.001)$ in calves from the first group compared to calves from the second group (Table 1).

Serum concentrations of total protein and globulin were significantly $(P<0.05$ and $P<0.001$; respectively) reduced in the first group compared to the second group (Table 2). Serum IGF-I concentrations were significantly higher $(P<0.01)$ in the second group compared to the first group (Table 2). Iron concentration showed significant positive correlation with serum IGF-I $(\mathrm{r}=0.624, P<0.01)$ only in calves from the second group; there was no significant correlation between iron and IGF-I concentrations in the calves from the first group $(\mathrm{r}=0.478 ; P>0.05)$. The data for all samples were homogenous $(\mathrm{Cv} \leq 30 \%)$ and in all cases the data distribution was according to the normal distribution model. Variance was homogenous. 
Table 1. Haematological indicators in iron-deficient calves (group 1) in comparison to calves with optimal iron concentration (group 2).

\begin{tabular}{lrrc}
\hline Indicators & \multicolumn{1}{c}{ Group 1 } & Group 2 & $P$ \\
\hline $\mathrm{RBC}\left(10^{6} / \mu \mathrm{l}\right)$ & $5.89 \pm 0.37$ & $9.70 \pm 0.16$ & $<0.001$ \\
$\mathrm{Hb}(\mathrm{g} / \mathrm{dl})$ & $5.91 \pm 0.41$ & $9.81 \pm 0.10$ & $<0.001$ \\
$\mathrm{HCT}(\%)$ & $21.21 \pm 1.48$ & $28.17 \pm 0.45$ & $<0.001$ \\
$\mathrm{MCV}(\mathrm{fl})$ & $35.91 \pm 1.15$ & $29.05 \pm 0.22$ & $<0.001$ \\
$\mathrm{MCH}(\mathrm{pg})$ & $10.02 \pm 0.35$ & $10.06 \pm 0.16$ & $\mathrm{~N}$ \\
$\mathrm{MCHC}(\%)$ & $279.03 \pm 6.52$ & $348.36 \pm 6.47$ & $<0.001$ \\
$\mathrm{TIBC}(\mu \mathrm{mol} / \mathrm{l})$ & $124.65 \pm 2.07$ & $87.45 \pm 1.19$ & $<0.001$ \\
\hline
\end{tabular}

RBC - erythrocyte count, $\mathrm{Hb}$ - haemoglobin concentration, HCT - haematocrit, MCV - mean corpuscular volume, $\mathrm{MCH}$ - mean corpuscular haemoglobin, $\mathrm{MCHC}$ - mean corpuscular haemoglobin concentration, TIBC - total iron binding capacity. Data are expressed as mean values $\pm \mathrm{SE}, P$ - significance, $\mathrm{N}$ - non-significant.

Table 2. Serum biochemical indicators in iron-deficient calves (group 1) in comparison to calves with optimal iron concentration (group 2).

\begin{tabular}{lrcc}
\hline Indicators & \multicolumn{1}{c}{ Group 1 } & Group 2 & $P$ \\
\hline Iron $(\mu \mathrm{mol} / \mathrm{l})$ & $7.34 \pm 0.36$ & $30.33 \pm 9.08$ & $<0.001$ \\
$\mathrm{IGF}-\mathrm{I}(\mathrm{nmol} / \mathrm{l})$ & $19.69 \pm 1.37$ & $27.77 \pm 2.32$ & $<0.01$ \\
Tp $(\mathrm{g} / \mathrm{l})$ & $57.14 \pm 1.15$ & $62.18 \pm 1.88$ & $<0.05$ \\
Alb $(\mathrm{g} / \mathrm{l})$ & $33.00 \pm 2.45$ & $24.61 \pm 0.73$ & $<0.01$ \\
Glo $(\mathrm{g} / \mathrm{l})$ & $24.14 \pm 2.22$ & $37.57 \pm 1.62$ & $<0.001$ \\
$\mathrm{~A} / \mathrm{G}$ & $1.47 \pm 0.19$ & $0.66 \pm 0.03$ & $<0.001$ \\
\hline
\end{tabular}

IGF-1 - insulin like growth factor-I, Tp - total protein, Alb - albumin, Glo - globulin, A/G - albumin globulin ratio. Data are expressed as mean values $\pm \mathrm{SE}, P$ - significance.

\section{Discussion}

The results of our study showed significant iron-related changes for most haematological and biochemical indicators in all calves with serum $\mathrm{Fe}<10 \mu \mathrm{mol} / \mathrm{l}$. Radostits et al. (2000) suggested the threshold value for serum Fe in cattle to be $<10 \mu \mathrm{mol} / \mathrm{l}$. According to Harvey (2008), these findings are usually combined with development of severe Fe deficiency, microcytic and hypochromic anaemia. Different iron reserves at birth can be expected to be responsible for differences in haematological indicators and indices of the iron metabolism (Morel 1996). Although concentrations of total protein were sufficient in both groups, significantly lower concentrations of total protein and globulin were detected in iron-deficient calves. This could be a consequence of the negative impact of iron deficiency on the IgG absorption (Eisa and Elgebaly 2010).

The relationship of haematology and serum chemistry indicators to IGF-I status was extensively studied in humans and laboratory rodents, and a close interaction between iron and IGF-I was reported by Choi and Kim (2004) and by Tran et al. (2012). In female adolescents, it is well established that serum IGF-I concentrations decrease gradually as body iron status falls (Choi and Kim 2004). However, limited data exist for large ruminants, especially calves, during the first weeks of postnatal life. In our study, we used a model of iron deficiency to gain information concerning a possible relationship of serum Fe and IGF-I concentrations in neonatal dairy calves. Calves exposed to iron deficiency 
anaemia presented a significant reduction in serum IGF-I compared to calves with optimal iron concentration on day 10 . The results obtained in our study are similar to other studies that investigated metabolic and endocrine changes during iron deficiency in veal calves (Ceppi and Blum 1994; Blum and Hammon 1999; Podhorský et al. 2007).

The IGF-I status markedly depends on energy and protein intake, as also shown in calves (Hammon and Blum 1998; Blum and Baumrucker 2002). Considering that the calves of both groups in our study received almost equal amounts of energy and protein, differences of serum IGF-I concentrations between groups were likely not due to these factors. Furthermore, it is known that other factors may also affect the production of IGF-I. The results of our study revealed that IGF-I in the circulations very strongly correlated with iron in calves with optimal iron concentration compared to iron-deficient calves. Although the positive correlation provides no indication of cause and effect, we consider that sufficient iron is required for normal secretion of IGF-I. Indeed, in situations of iron deficiency in rats, iron is a critical determinant of IGF-I regulation (Tran et al. 2012), and previous research has also shown that iron deficiency reduces GH-mediated IGF-I secretion (Ceppi and Blum 1994). Nevertheless, conversely to what was observed in the iron deficiency state, parenteral administration of iron in calves during the early postnatal period resulted in a rise of serum IGF-I concentrations (Moosavian et al. 2010). The significant reduction of serum IGF-I observed in iron-deficient calves is therefore more likely a consequence of altered iron status, indicating an important relationship between the iron status and IGF-I activity in 10-day-old calves.

In conclusion, iron deficiency in 10-day-old calves has an important impact on IGF-I concentration. Therefore, the monitoring of Fe status in newborn calves is essential not only for the achievement of good health but also for the achievement of adequate weight gain of young calves due to the involvement of the IGF system in proper utilization of consumed nutrients in the animals.

\section{Acknowledgements}

This work was supported by Ministry of Education, Science and Technological Development, Republic of Serbia (project number: III 46002).

\section{References}

Blum JW, Baumrucker CR 2002: Colostral and milk insulin-like growth factors and related substances: Mammary gland and neonatal (intestinal and systemic) targets. Domest Anim Endocrinol 23: 101-110

Blum JW, Hammon H 1999: Endocrine and metabolic aspects in milk-fed calves. Domest Anim Endocrinol 17: 219-230

Bostedt H, Jekel E, Schramel P 1990: The development of iron and copper concentrations in blood plasma of calves in the first days and weeks of life, equally a contribution to the larvaceous neonatal iron deficiency anemia (in German). Deut Tierärztl Woch 97: 400-403

Ceppi A, Blum JW 1994: Effects of growth hormone on growth performance, haematology, metabolites and hormones in iron-deficient veal calves. J Vet Med A 41: 443-458

Choi JW, Kim SK 2004: Association of serum insulin-like growth factor-I and erythropoiesis in relation to body iron status. Ann Clin Lab Sci 34: 324-328

Cordano P, Hammon HM, Morel C, Zurbriggen A, Blum JW 2000: mRNA of insulin-like growth factor (IGF) quantification and presence of IGF binding proteins, and receptors for growth hormone, IGF-I and insulin, determined by reverse transcribed polymerase chain reaction, in the liver of growing and mature male cattle. Domest Anim Endocrinol 19: 191-208

Eisa AMA, Elgebaly LS 2010: Effect of ferrous sulphate on haematological, biochemical and immunological parameters in neonatal calves. Vet Ital 46: $329-335$

Guilloteau P, Biernat M, Woliński J, Zabielski R 2002: Gut regulatory peptides and hormones of the small gut. In: Zabielski R, Gregory PC, Weström B (Eds). Biology of the Intestine in Growing Animals. Elsevier, Amsterdam, pp. 325-362

Hammon H, Blum JW 1998: Metabolic and endocrine traits of neonatal calves are influenced by feeding colostrum for different duration or only milk replacer. J Nutr 128: 624-632

Harvey JW 2008: Iron metabolism and its disorders. In: Kaneko JJ, Harvey JW, Bruss ML (Eds): Clinical Biochemistry of Domestic Animals, $6^{\text {th }}$ edn. Academic Press, San Diego, pp. 259-285 
Kirovski D, Lazarević M, Baričević-Jones I, Nedić O, Masnikosa R, Nikolić JA 2008: Effects of peroral insulin and glucose on circulating insulin-like growth factor-I, its binding proteins and thyroid hormones in neonatal calves. Can J Vet Res 72: 253-258

Lindt F, Blum JW 1994: Occurrence of iron deficiency in growing cattle. J Vet Med A 41: 237-246

Mohri M, Poorsina S, Sedaghat R 2010: Effects of parenteral supply of iron on RBC parameters, performance, and health in neonatal dairy calves. Biol Trace Elem Res 136: 33-39

Moosavian HR, Mohri M, Seifi HA 2010: Effects of parenteral over-supplementation of vitamin A and iron on hematology, iron biochemistry, weight gain, and health of neonatal dairy calves. Food Chem Toxicol 48: $1316-1320$

Morel I 1996: Iron supply in veal calves (in German). Agrarforschung 3: 53-56

Podhorský A, Pehová A, Dvořák R, Pavlata L 2007: Metabolic disorders in dairy calves in postpartum period. Acta Vet Brno 76: 45-53

Radostits OM, Gay CC, Blood DC, Hinchcliff KW 2000: Veterinary Medicine, $9^{\text {th }}$ edn. Saunders, Philadelphia, PA, USA, $1875 \mathrm{p}$.

Tran PV, Fretham SJ, Wobken J, Miller BS 2012: Georgieff MK. Gestational-neonatal iron deficiency suppresses and iron treatment reactivates IGF signaling in developing rat hippocampus. Am $\mathrm{J}$ Phys Endo Met 302: 316-324 